\section{AGRIEKONOMIKA}

http://journal.trunojoyo.ac.id/agriekonomika

Volume 10, Nomor 1, 2021

https://doi.org/10.21107/agriekonomika.v10i1.9890
Agriekonomika has been accredited as a scientific journal by the Ministry of

Research-Technology and Higher

Education Republic of Indonesia: No.

23/E/KPT/2019

\title{
Modal Sosial Petani Rehabilitasi dalam Pemulihan Ekosistem Taman Nasional Meru Betiri
}

\author{
Isa Mariyani \& Luh Putu Suciati \\ Program Studi Agribisnis Fakultas Pertanian Universitas Jember, Indonesia \\ Received: Februari 2021; Accepted: April 2021; Published: April 2021
}

\begin{abstract}
ABSTRAK
Lahan kritis di wilayah Taman Nasional Meru Betiri yang dikategorikan terluas di Jawa Timur memerlukan dukungan para pihak untuk berpartisipasi. Keberhasilan kegiatan pemulihan ekosistem tersebut memerlukan dukungan utama dari petani rehabilitasi di sekitar kawasan penyangga taman nasional. Tujuan penelitian adalah menganalisis keberadaan modal sosial petani rehabilitasi dalam kerjasama pemulihan ekosistem pada kawasan konservasi di Resort Wonoasri Taman Nasional Meru Betiri. Metode penelitian menggunakan deskriptif analitik dengan skala guttman dan instrumen SCAT (Social Capital Assessment Tools). Hasil penelitian menunjukkan bahwa modal sosial petani rehabilitasi dalam kerjasama pemulihan ekosistem adalah kuat dengan unsur kepercayaan (skor 95.31 persen), unsur norma (skor 64.06 persen) dan unsur jaringan sosial (skor 58.85 persen). Potensi modal sosial yang kuat dapat mendorong partisipasi aktif anggota kelompok LMDHK Wonomulyo yang saat ini cenderung pasif. Komunikasi yang baik dengan bahasa yang difahami oleh masyarakat desa hutan terus dilakukan secara intensif dan berkesinambungan yang ditunjang dengan transparansi informasi untuk meminimalkan konflik pengelolaan lahan dan meningkatkan pemulihan ekosistem di Taman Nasional Meru Betiri.
\end{abstract}

Kata kunci: Pemulihan Ekosistem, Modal Sosial, SCAT.

\section{The Social Capital of Rehabilitation Farmer in Ecosystem Recovery of Meru Betiri National Park}

\begin{abstract}
Critical land in the Meru Betiri National Park area which is categorized as the largest in East Java requires the support of all parties to participate. The success of these ecosystem restoration activities requires the main support of rehabilitation farmers around the buffer zone of the national park. The purpose of the study was to analyze the existence social capital of rehabilitation farmers in collaboration with ecosystem restoration in a conservation area at the Wonoasri Resort, Meru Betiri National Park. The research method uses descriptive analytic with guttman scale and SCAT (Social Capital Assessment Tools) instrument. The results showed that the social capital of rehabilitation farmers in ecosystem restoration collaboration was strong with aspects of trust (score 95.31 percent), aspects of norms (score 64.06 percent) and aspects of social networks (score 58.85 percent). The potency of strong social capital can encourage the active participation of members of the Wonomulyo LMDHK (conservation forest community society group, which currently tends to be passive. Good communication in a language that is understood by forest village communities continues to be carried out intensively and continuously supported by information transparency to minimize land management conflicts and improve ecosystem recovery in Meru Betiri National Park.Keyword: Aging Farmer, Education, Agriculture, Labour.
\end{abstract}

Keywords: Ecosystem Restoration, Social Capital, SCAT.

\footnotetext{
Corresponding author:

Email : mariyaniisa7@gmail.com
} 


\section{PENDAHULUAN}

Berdasarkan Undang-undang Nomor 5 Tahun 1990 tentang Konservasi Sumber Daya Alam Hayati dan Ekosistemnya, bab 1 pasal 1 ayat 14, mendefinisikan Taman Nasional (TN) adalah kawasan pelestarian alam yang mempunyai ekosistem asli, dikelola dengan sistem zonasi yang dimanfaatkan untuk tujuan penelitian, ilmu pengetahuan, pendidikan, menunjang budidaya, pariwisata, dan rekreasi. Taman nasional di Indonesia sebanyak 54 unit taman nasional dan salah satunya yaitu Taman Nasional Meru Betiri dengan luas sebesar 52.626,04 Ha (Direktorat Jenderal KSDAE, 2019). Prosentase luasan lahan kritis yang tinggi sebesar $2.779,08 \mathrm{Ha}$ (Tabel 1) di dalam kawasan konservasi memerlukan pemulihan ekosistem mengingat peran dan fungsi taman nasional. Pemulihan ekosistem merupakan salah satu upaya untuk memperbaiki kondisi hutan yang telah rusak, selain itu untuk menjaga kelestarian sumber daya alam, flora dan fauna yang terdapat di dalamnya. Berikut luas lahan kritis di dalam kawasan konservasi taman nasional Jawa Timur.

Luas lahan kritis Taman Nasional Meru Betiri mengalami kenaikan pada tahun 2016 dan pada tahun 2017 tidak mengalami perubahan yaitu tetap seluas $2.779,08 \mathrm{Ha}$. Tingginya luas lahan kritis di kawasan konservasi Taman Nasional Meru Betiri disebabkan adanya illegal logging. Hal ini dibuktikan dalam laporan data potensi gangguan, ancaman, dan pelanggaran hukum kehutanan tahun 2017, selain itu juga dikarenakan pembakaran lahan yang dilakukan dengan sengaja, pemeliharaan tanaman yang kurang sehingga menyebabkan tanaman mati dan penyebab cuaca kering ekstrim sehingga banyak tanaman pokok yang mati (Dinas Kehutanan, 2018).

Istilah pemulihan ekosistem di Indonesia sudah dikenal sejak beberapa dekade lalu dengan berbagai istilah mulai reboisasi, rehabilitasi, penghijauan, dan reforestasi. Berbagai inisiatif kebijakan tersebut merupakan bentuk komitmen pemerintah dalam memulihkan ekosistem yang telah terganggu atau rusak. Komitmen lahir atas dasar pentingnya mengembalikan berbagai fungsi ekosistem yang terdegradasi mulai dari fungsi penjaga keanekaragaman hayati, penyediaan pangan dan energi, dan jasa lingkungan (Susmianto dkk., 2017). Kondisi kawasan konservasi yang mengalami degradasi perlu dilakukan perbaikan ekosistem (Sahruddin dkk 2019). Tahapan-tahapan kegiatan pelaksanaan pemulihan ekosistem salah satunya yaitu penyusunan Rencana Kegiatan Pemulihan Ekosistem (PE) TNMB 2016 - 2020 yang melibatkan masyarakat sekitar kawasan dan lembaga masyarakat yaitu Lembaga Masyarakat Desa Hutan Konservasi (LMDHK).

Kegiatan pemulihan ekosistem dihadapkan pada permasalahan terkait peran masyarakat penyangga taman nasional. Beberapa kasus pelanggaran pemanfaatan lahan taman nasional dihadapkan pada kurangnya kesadaran masyarakat untuk memelihara tanaman

Tabel 1

Luas Lahan Kritis di dalam Kawasan Konservasi Tahun 2013-2017

\begin{tabular}{llccccc}
\hline No. & Lokasi & \multicolumn{5}{c}{ Lahan Kritis di Dalam Kawasan Hutan (Ha) } \\
\cline { 3 - 6 } & & 2013 & 2014 & 2015 & 2016 & 2017 \\
\hline 1. & BTN. Baluran & 150,00 & - & - & - & - \\
2. & BTN. Meru Betiri & $2.733,50$ & $2.733,50$ & $2.733,50$ & $2.779,08$ & $2.779,08$ \\
3. & BBTN. Bromo & $4.065,00$ & - & - & - & - \\
& Tengger Semeru & & & & & - \\
4. & BTN. Alas Purwo & - & - & - & - & - \\
\hline
\end{tabular}

Keterangan: BTN (Balai Taman Nasional), BBTN (Balai Besar Taman Nasional)

Sumber: Dinas Kehutanan Provinsi Jawa Timur, 2018 
pokok, adanya illegal logging dan pembakaran lahan sehingga target penanaman tanaman pokok atau tutupan lahan sebanyak 400 pohon per hektar belum terpenuhi. Kondisi demikian memerlukan studi terkait aspek kemasyarakatan agar kegiatan pemulihan ekosistem dalam optimal. Aspek sosial kemasyarakatan merupakan hal penting yang diharapkan mampu mengatasi pemasalahan tingginya lahan kritis di Taman Nasional Meru Betiri. Salah satunya melalui kajian modal sosial, harapannya adalah dengan mengetahui derajat modal sosial petani rehabilitasi kan mampu mengatasi permasalahan lingkungan. Modal sosial memiliki peranan penting dalam suatu kegiatan salah satunya yaitu pemulihan (recovery) terutama melalui unsur trust, nilai dan norma, serta jaringan sosial untuk mendorong partisipasi masyarakat, pemerintah, lembaga swadaya masyarakat, dan kalangan pelaku usaha dalam upaya menciptakan kondisi sosial ekonomi seperti sebelum terjadi kerusakan pada ekosistem (Usman, 2018). Berdasarkan uraian di atas tujuan penelitian adalah menganalisis modal sosial petani rehabilitasi dalam pelaksanaan Pemulihan Ekosistem (PE) kawasan konservasi di Resort Wonoasri Taman Nasional Meru Betiri.

\section{METODE PENELITIAN}

Metode penelitian yang digunakan yaitu deskriptif analitik dengan jenis data data sekunder dan data primer. Sumber data sekunder diperoleh dari jurnal, artikel, dan buku. Sumber data primer diperoleh dengan pengumpulan data melalui observasi lapang dan wawancara terstruktur. Jumlah populasi petani mitra di Resort Wonoasri, Taman Nasional Meru Betiri sejumlah 16 kelompok tani lahan rehabilitasi yang tersebar pada 4 blok dengan jumlah total sekitar 650 petani. Penentuan responden informan kunci menggunakan teknik non probability sampling melalui pendekatan sampling kuota (sampel kuota) yaitu ketua kelompok tani atau pengurus yang aktif. Jumlah informan kunci yang dipilih sejumlah 4 orang per blok dalam 4 blok/ kelompok yang aktif bekerjasama dalam kegiatan pemulihan ekosistem di Resort Wonoasri Taman Nasional Meru Betiri, sehingga informan kunci pada penelitian sebanyak 16 petani. Selain itu dilakukan indepth interview secara purposive dengan ketua LMDHK Wonomulyo, pengurus inti (sekretaris dan bendahara) serta petugas taman nasional (penyuluh kehutanan dan Kepala Resort Wonoasri untuk melengkapi informasi data dari ketua kelompok tani anggota LMDHK Wonomulyo.

Metode analisis dalam penelitian ini menggunakan analisis deskriptif dengan skoring. Indikator modal sosial untuk menganalisis tingkat modal sosial petani rehabilitasi menggunakan unsur modal sosial Putnam (1993), yaitu kepercayaan (trust), norma-norma (norms), dan jaringan sosial (social network). Skala pengukuran menggunakan skala guttman untuk mendapatkan jawaban tegas yaitu "iya" dan "tidak" terhadap suatu permasalahan (Triana \& Oktavianto, 2013). Sejumlah 12 pertanyaan dengan ukuran skala guttman selanjutnya dikonversikan ke dalam persentase sehingga terlihat persentase yang kuat dan tidak kuat. Menurut Iskani (2015), untuk memudahkan memberikan penilaian secara operasional maka digunakan rentang skala persentase. Oleh karena itu pada pengukuran tingkat modal sosial petani lahan rehabilitasi Taman Nasional Meru Betiri dikategorikan menjadi 3 tingkatan yaitu, mendekati tidak kuat, mendekati kuat dan tidak kuat, dan mendekati kuat. Penetapan kategori ini juga dilakukan oleh Iskan (2015), sehingga kategori tingkat modal sosial petani rehabilitasi pada penelitian ini adalah

a. Tingkat modal sosial dalam Pemulihan Ekosistem (PE) kawasan konservasi Taman Nasional Meru Betiri mendekati tidak kuat, jika skor aspek modal sosial $<0-50 \%$.

b. Tingkat modal sosial dalam Pemulihan Ekosistem (PE) kawasan konservasi Taman Nasional Meru Betiri mendekati tidak kuat dan mendekati kuat, jika skor aspek modal sosial $\geq 50 \%$. 
c. Tingkat modal sosial dalam Pemulihan Ekosistem (PE) kawasan konservasi Taman Nasional Meru Betiri mendekati kuat, jika skor aspek modal sosial $>50$ $-100 \%$.

\section{HASIL DAN PEMBAHASAN}

Keberhasilan program, salah satunya dapat pula oleh modal sosial yang dimiliki petani, menurut Putnam (1993) modal sosial terdiri dari tingkat kepercayaan, norma-norma, dan jaringan sosial. Modal sosial sebenarnya sudah melekat pada petani sebelum adanya lembaga LMDHK mengkoordinir kegiatan pemulihan ekosistem. Komunitas kelompok tani hutan secara sukarela bergotong royong dalam pembenahan infrastruktur jalan desa dan jembatan penghubung antar dusun sampai kegiatan penghijauan di kawasan konservasi taman nasional. Pada pengelolaan lahan rehabilitasi di Taman Nasional Meru Betiri, petani yang terikat perjanjian kerjasama memiliki rasa tanggung jawab secara bersamasama untuk mengikuti dan menaati setiap aturan yang diberikan oleh petugas taman nasional seperti menanam, merawat, dan menjaga kawasan konservasi dari gangguan baik hama, penyakit, maupun manusia. Hasil kajian skor tingkat modal sosial petani rehabilitasi Taman Nasional Meru Betiri dalam kerjasama pemulihan ekosistem berdasarkan unsur nilai kepercayaan sebesar 95,31 persen, skor unsur nilai norma sebesar 64,06 persen dan skor unsur jaringan sosial sebesar 58,85 persen. Berdasarkan hasil kajian tersebut maka secara keseluruhan kategori modal sosial petani rehabilitasi mendekati kuat dengan nilai persentase sebesar 72,74 persen. Berikut diskripsi masing-masing unsur pembentuk modal sosial.

\section{Unsur Kepercayaan pada Modal Sosial}

Kepercayaan komunitas masyarakat akan pihak lain dapat terjadi antar kelompok dan dengan stakeholder lainnya, seperti pihak pemerintah, perusahaan, dan juga LSM (Oktadiyani dkk., 2013). Unsur nilai kepercayaan petani rehabilitasi dapat diketahui dari interaksi sosial yang terjalin antara petani rehabilitasi dengan berbagai pihak yaitu sesama petani rehabilitasi, LMDHK Wonomulyo, dan petugas taman nasional. Penilaian skoring aspek kepercayaan yang Nampak pada interaksi sosial dengan sesama petani rehabilitasi berada dalam kategori mendekati kuat dengan persentase sebesar 92.19 persen. Hal ini dikarenakan sebagian besar petani sudah mempercayai LMDHK dan Balai Taman Nasional Meru Betiri dalam menjalankan tugasnya untuk mengarahkan dan membina petani, petani saling membantu, mengarahkan. Namun, demikian terdapat sebagian kecil petani masih belum percaya pada arahan dan instruksi dari Taman Nasiona Meru Betiri sehingga masih melakukan kecurangan dalam penanaman seperti menanam tanaman pokok tidak sesuai dengan jumlah bantuan yang diberikan, lebih memilih menanam tanaman MPTS (Multi Purpose Trees Species) yang memiliki nilai ekonomi dibandingkan dengan tanaman endemik dan menanam tanaman musiman yang tidak dianjurkan seperti tanaman peje (Pueraria Javanica). Nampak bahwa aspek kepercayaan antar petani dapat mempengaruhi pola pikir dalam kegiatan pemulihan ekosistem.

Nilai prosentase skor unsur kepercayaan dan interaksi sosial petani dengan LMDHK Wonomulyo berada dalam kategori mendekati kuat dengan persentase sebesar 95,31 persen. Tingginya kepercayaan karena pihak Taman Nasional membantu persiapan bibit, memberikan bantuan bibit, sosialisasi/ pengarahan, meringankan masalah petani, melakukan pengawasan, dan pemasaran hasil social forestry. Sementara peran LMDHK Wonomulyo melengkapi dengan memberikan akses pemasaran hasil sosial forestri meliputi tanaman mengkudu, asem, kemiri, mangga, pete dan lainlain hasil dari pohon pokok. Walaupun kepercayaan petani sudah cukup kuat, namun masih terdapat sebagian kecil yang belum memahami kegiatan yang 
ada dalam LMDHK Wonomulyo sehingga cenderung bersikap pasif.

Pada sisi lain, nilai skor unsur kepercayaan dan interaksi sosial dengan petugas Balai Taman Nasional Meru Betiri berada dalam kategori mendekati kuat dengan persentase sebesar 98,44 persen. Sebagian besar petani percaya kepada petugas taman nasional yang senantiasa membantu petani ketika menghadapi permasalahan. Dukungan dari petugas Taman Nasional untuk kegiatan pemulihan ekosistem sangat beragam dan tidak terbatas pada petani tetapi juga pada istri petani dan keluarganya. Beberapa pelatihan dan kegiatan peningkatan kapasitas petani dilakukan untuk menjembatani keterbatasan pengetahuan dan akses informasi teknologi. Pelatihan bagi ibu-ibu petani dan dukungan untuk anak-anak petani dalam bentuk program pendidikan.

\section{Unsur Norma pada Modal Sosial}

Unsur norma pada modal sosial petani dilihat berdasarkan kepatuhan petani rehabilitasi dalam perjanjian kerjasama pengelolaan lahan rehabilitasi serta sanksi dan pemberlakuan sanksi dalam pelanggaran peraturan kerjasama. Hasil pengukuran tingkat kepatuhan terhadap peraturan dalam perjanjian kerjasama pengelolaan lahan rehabilitasi berada pada kategori mendekati tidak kuat dengan persentase 48,44 persen. Rendahnya skoring dikarenakan peraturan berupa perjanjian kerjasama pemulihan ekosistem bersifat tertulis yang mengikat antara petani dengan taman nasional, sedangkan persepsi petani yang tergabung di dalam LMDHK Wonomulyo menyatakan bahwa tidak ada aturan yang mengikat anggota di LMDHK untuk pengelolaan lahan rehabilitasi maupun kelembagaan.

Aturan atau norma sosial merupakan suatu keharusan, larangan, pantangan, dan tanggung jawab yang dilakukan secara sendiri-sendiri maupun bersamasama (Anen, 2016). Sebagian besar petani sudah mengetahui peraturan perjanjian kerjasama dalam kegiatan pemulihan ekosistem, yaitu boleh menanam tetapi tidak boleh memperjualbelikan lahan garapan dan harus dirawat serta tidak boleh merusak tanaman. Aturan penanaman yaitu dianjurkan menanam 100 pohon per patok (0.25 ha). Adanya aturan tertulis kerjasama kegiatan pemulihan ekosistem bersifat mengikat petani misalnya pemilihan tanaman pokok dan kewajiban serta hak terhadap tanaman pokok tanaman dan aturan memperjualbelikan lahan garapan. Kepatuhan terhadap norma pada atuean membuat pemulihan ekosistem menjadi semakin baik dan tingkat kesejahteraan meningkat karena petani mengetahui hak dan kewajiban memanfaatkan tanaman MPTS (Multi Purpose Trees Species)yang bernilai ekonomi.

Hak dan kewajiban petani diatur dalam perjanjian kerjasama pemulihan ekosistem. Kewajiban petani yaitu menanam tanaman pokok minimal 100 batang/patok (1 patok $=0.25 \mathrm{ha}$ ), mematuhi petunjuk teknis dari taman nasional, menyediakan bibit secara swadaya untuk tanaman yang mati, dan turut serta menjaga, mengamankan, dan melindungi kawasan Taman Nasional Meru Betiri dari gangguan, kerusakan dan kebakaran. Hak petani yaitu menerima bantuan bibit, memanen buah/biji dari tanaman pokok yang ada, mengelola tanaman musiman dengan jenis yang telah ditentukan meliputi, jagung, padi, kedelai, cabai jawa, kacang-kacangan, pisang, singkong, dan ubi jalar. Tanaman musiman yang tidak dianjurkan oleh taman nasional yaitu peje (Pueraria Javanica).

Sanksi dan pemberlakuan sanksi dalam pelanggaran peraturan kerjasama berada dalam kategori mendekati kuat dengan persentase sebesar 95.31 persen. Hal ini, karena sebagian besar petani sudah mengetahui sanksi, namun sebagian kecil petani belum mengetahui secara jelas sanksi dalam perjanjian kerjasama pemulihan ekosistem. Urutan sanksi pelanggaran kerjasama pemulihan ekosistem yaitu mendapatkan peringatan, pembinaan, dan pencabutan hak garap dari pihak taman nasional. Pencabutan hak garap diberlakukan apabila petani 
melakukan pelanggaran kembali setelah dilakukan pembinaan dan peringatan sebanyak tiga kali, kemudian lahan rehabilitasi akan dikembalikan ke taman nasional yang akan dimanfaatkan untuk tujuan penelitian, pendidikan, atau dibiarkan menjadi hutan secara alami. Larangan dalam kegiatan pemulihan ekosistem yang terdapat dalam perjanjian kerjasama sebagai berikut:

a. Dilarang menebang/merusak tanaman pokok (memangkas cabang serta daun tanaman pokok)

b. Dilarang memperjualbelikan lahan garapannya dan/atau memindah tangankan lahan garapan kepada pihak lain

c. Dilarang menambah luas lahan garapan

d. Dilarang merubah fungsi hutan menjadi areal persawahan

e. Dilarang melakukan pembakaran di dalam kawasan taman nasional.

\section{Unsur Jaringan Sosial pada Modal Sosial}

Menurut Fadilah (2016), tingkat jaringan sosial yaitu jaringan yang terbentuk karena komunikasi, interaksi dan relasi individu dengan individu lain dalam komunitas atau dengan individu di luar komunitas. Jaringan sosial petani rehabilitasi merupakan luas jaringan yang dijalin oleh petani rehabilitasi dengan berbagai pihak. Tingkat jaringan sosial dilihat berdasarkan bentuk/tipologi modal sosial yaitu, social bounding, social bridging, dan social linking. Social bounding petani rehabilitasi berada pada kategori mendekati kuat dengan persentase 64.06 persen. Unsur Social Bounding mendekati kuat, karena hubungan yang terjalin antar petani rehabilitasi baik yaitu bekerjasama dalam mengelola lahan rehabilitasi, bertukar informasi, membantu memberikan bibit, dan menanam tanaman pokok, serta memberikan arahan kepada petani. Namun, ada sebagian kecil petani tidak pernah bertukar informasi dengan petani rehabilitasi lain karena jarang ke lahan rehabilitasi. Sebagian besar petani mengenal semua petani di dalam LMDHK
Wonomulyo, namun ada sebagian petani yang hanya mengenal beberapa petani rehabilitasi.

Unsur social bridging yaitu berkaitan dengan hubungan yang terjalin antara petani dengan petani lain atau petani desa. Hubungan ini dalam bentuk partisipasi petani, sharing pengalaman dan kerjasama antara petani rehabilitasi dengan petani desa. Social bridging petani rehabilitasi berada pada kategori mendekati tidak kuat. Hal ini, karena sebagian besar petani tidak memiliki hubungan dengan petani lain selain petani rehabilitasi (petani desa). Namun, sebagian kecil petani ada yang memiliki hubungan dengan petani selain petani rehabilitasi (petani desa) karena berkaitan dengan pekerjaaan yaitu sebagai pedagang dan pekerja (buruh).

Unsur social linking yaitu hubungan yang terjalin antara petani dengan Taman Nasional Meru Betiri dan pihak lain yang terlibat dalam kegiatan pemulihan ekosistem. Social linking petani rehabilitasi berada pada kategori mendekati kuat dengan persentase 73,44 persen. Hal ini, karena sebagian besar petani memiliki hubungan baik dengan lembaga terkait yaitu LMDHK Wono Mulyo dan Resort Wonoasri Taman Nasional Meru Betiri. Petani memiliki hubungan baik dengan LMDHK Wono Mulyo dan taman nasional yaitu petani mendapatkan bantuan bibit tiap tahun, petani secara bersama - sama memecahkan masalah petani seperti pemasaran hasil social forestry, meminta saran seperti tata cara penanaman dan jenis tanaman yang lebih menghasilkan, mengikuti kegiatan penanaman dan pemanenan hasil, serta memasarkan hasil social forestry ke LMDHK. Sebagian besar petani sudah memasarkan tanaman ke LMDHK Wonomulyo meliputi tanaman asem, mengkudu, pete, mangga dan jambu mente. Bahkan LMDHK Wono Mulyo sudah bekerjasama dalam skala regional Jawa Timur yaitu dengan PT. Maspil. Untuk menguatkan jaringan kerjasama, pihak Balai Taman Nasional Meru Betiri memberikan kepercayaan kepada petani melalui LMDHK untuk kegiatan penyediaan 
bibit untuk kegiatan pemulihan ekosistem melalui bidang usaha nursery. Hal ini memberikan indikasi kuatnnya unsur jaringan petani dengan beberapa pihak. Bentuk jaringan lainnya adalah kerjasama dengan Perguruan Tinggi (Universitas Jember) pada kegiatan hibah Bappenas RI dalam ICCTF(Indonesia Climate Change Trust Fund) melalui bantuan bibit tanaman endemik dan MPTS (Multi Purpose Trees Species) pada tahun 2017 untuk dengan total jumlah tanaman 91,824 batang meliputi durian, kemiri, pakem, dan langsep, serta pada tahun 2018 untuk kegiatan penanaman 10,500 batang dan kegiatan pemeliharaan 1,050 batang meliputi tanaman durian, kemiri, alpukat, aren, langsep, dan pete.

\section{SIMPULAN}

Keberadaan modal sosial yang kuat sangat mendukung keberhasilan program pemulihan ekosistem lahan rehabilitasi pada lahan kritis di Taman Nasional Meru Betiri. Unsur modal sosial seperti kepercayaan, norma dan jaringan sosial akan meningkatkan kepercayaan pihak lain yang bekerjasama dengan petani. Pada penelitian ini unsur modal sosial relatif mendekati kuat (skor 72,74) dengan kekuatan unsur kepercayaan yang paling tinggi skor 95.31 persen), disusul unsur norma (skor 64.06 persen) dan paling rendah adalah unsur jaringan sosial (skor 58.85 persen). Rendahnya unsur norma dan jaringan sosial berimplikasi pada masih rendahnya capaian pemulihan ekosistem lahan rehabilitasi Taman Nasional Meru Betiri, oleh karena itu perlu komunikasi yang baik dengan petani dengan logika sosial yang dapat diterima. Rendahnya jaringan sosial perlu ditingkatkan dengan tatakelola dan manajemen kelompok melalui LMDHK Wonomulyo agar partisipasi petani lebih baik untuk pemulihan ekosistem.

\section{DAFTAR PUSTAKA}

Anen, N. (2016). Peran Modal Sosial Masyarakat Dalam Pengelolaan. Nusa Sylva, 16(2), 72-81.
Dinas Kehutanan. (2018). Kehutanan Dalam Angka Provinsi Jawa Timur Tahun 2013-2017. Sidoarjo: Dinas Kehutanan Jawa Timur.

Direktorat Jenderal KSDAE. (2019). Statistik Direktorat Jenderal Konservasi Sumber Daya Alam dan Ekosistem Tahun 2018. Jakarta: Kementrian Lingkungan Hidup dan Kehutanan.

Fadilah, A. Z. (2016). Hubungan Modal Sosial Dengan Partisipasi Masyarakat Dalam Pengelolaan Hutan Bersama Masyarakat (PHBM) (Kasus LMDH Rimba Mulya, Desa Kalimendong, Keamatan Leksono, Kabupaten Wonosobo). Institut Pertanian Bogor.

Iskani. (2015). Pengukuran Skala Guttman Secara Tradisional ( Cross Sectional ). Retrieved from ejournal.poltektegal.ac.id website: https://www.google.com/url?sa= $\mathrm{t} \&$ source=web\&rct=j\&url=http:// ejournal.poltektegal.ac.id/index.php/ informatika/article/downloadSuppFil e/832/345\&ved=2ahUKEwiUspDhuJ fuAhW8IEsFHbPdCkIQFjAAegQIAR AB\&usg=AOvVaw2Lxv4JJcDGRUG ycskcA-Xa\&cshid=1610491632116.

Oktadiyani, P., Muntasib, E. K. S. H., \& Sunkar, A. (2013). Modal Sosial Masyarakat di Kawasan Penyangga Taman Nasional Kutai (Tnk) dalam Pengembangan Ekowisata. Media Konservasi, 18(1), 1-9.

Sahruddin, S., Tjoneng, A., \& Numba, S. (2019). Kajian Kawasan Terdegradasi Dan Pola Pemulihan Ekosistem di Kawasan Suaka Marga Satwa Ko'Mara Kabupaten Takalar. AGROTEK: Jurnal IImiah IImu Pertanian, 2(2), 1-14. https://doi. org/10.33096/agrotek.v2i2.57. 
58 | Isa Mariyani \& Luh Putu Suciati, Modal Sosial Petani Rehabilitasi dalam Pemulihan Ekosistem

Susmianto, A., Wawandono, N. B., Triana, D., \& Oktavianto, W. O. (2013). Triswanto, A., Pujiati, Munawir, A., Gunawan, Gumilang, R. S. (2017). Kisah Keberhasilan Pemulihan Ekosistem di Kawasan Suaka Alam dan Kawasan Pelestarian Alam Secara Partisipasif. In Journal of Chemical Information and Modeling (Vol. 53). Jakarta: Forda Relevansi Kualifikasi Kontraktor Bidang Teknik Sipil Terhadap Kualitas Pekerjaan Proyek Konstruksi Di Provinsi Banten. Jurnal Fondasi, 1(1), 182-190.

Usman, S. (2018). Modal Sosial. Yogyakarta: Pustaka Pelajar.

Press. https://doi.org/10.1017/ CBO9781107415324.004. 